\title{
INNOVATION, CORRUPTION, AND ECONOMIC GROWTH IN EMERGING ASIA
}

\author{
Aurolipsa Das*, Devi Prasad Dash**, and Narayan Sethi*** \\ * Dept. of Humanities and Social Sciences, National Institute of Technology, Rourkela, India. Email: \\ aurolipsa12@gmail.com \\ ** Corresponding Author. School of Management and Entrepreneurship (SME), \\ Indian Institute of Technology (IIT), Jodhpur, India. Email: devi100.dash@gmail.com \\ *** Dept. of Humanities and Social Sciences, National Institute of Technology, Rourkela, India. Email: \\ nsethinarayan@gmail.com
}

\begin{abstract}
In this paper, we investigate the impact of innovation and corruption on economic growth for 13 emerging Asian economies over the period of 2009 to 2018. Using global innovation and corruption indices, we show that innovation has no significant impact on growth. In contrast, corruption slows down growth in the region. Our results indicate that innovation in the region is not robust enough to attract growth and that corruption is the major hindrance to growth.
\end{abstract}

Keywords: Innovation; Corruption; Economic growth; Asia; Quantile regression.

JEL Classifications: O31; D73; O40; O53.

\author{
Article history: \\ Received : October 20, 2019 \\ Revised : : December 22, 2019 \\ Accepted : June 02, 2020 \\ Available online : October 30, 2020 \\ https://doi.org/10.21098/bemp.v23i3.1183
}




\section{INTRODUCTION}

In this paper, we investigate the impact of innovation and corruption on economic growth. Economic growth is said to be determined by an array of factors and the interplay of both macro and microeconomic elements. Several growth theories postulated the importance of capital and labour (Harrod, 1939; Domar, 1946; Solow, 1956; Uzawa, 1964) and others improved upon these factors by considering the role of investment in human capital, innovation, and knowledge in significantly driving economic growth (Romer, 1994; Juhro et al., 2020). In the recent past, another strand of literature has emerged, called new institutional economics, and this literature pinpoints the importance of institutions in economic growth (Douglas,1993). This literature defined institutions as 'the rules of the game of a society or more formally are the humanly-devised constraints that structure human interaction' (Douglas,1993, p.5).

The interaction between institutions and organizations play a crucial role in deciding the course of an economy, as may other economic factors. Corruption is a global phenomenon and is not particularly related to any economy per se. As corruption becomes endemic among the population, honesty becomes a deviant behavior and, consequently, the former becomes the rules of the games, also known as institutions (Teorell, 2007). Corruption disturbs the political and economic setup of an economy and thereby decreases the pace of economic growth by decreasing investments (Craigwell and Wright, 2012; Mauro, 1995; Tanzi, 1998; Blackburn and Powell, 2011). However, corruption is also viewed as a grease for the wheels of economic growth (Leff, 1964). Innovation, on the other hand, which may cover under its umbrella, research and development (R\&D) activities, expenditure on the same, and number of patents and country of origin, is widely perceived as a tool to accelerate economic growth (Juhro et al., 2020; Maradana et al., 2017; Andergassen et al., 2009; Cameron,1998).

Transparency International defines corruption as 'the abuse of entrusted power for private gain' and provides the scores for the level of corruption in selected countries through the years, the so-called Corruption Perception Index (CPI) ${ }^{1}$.

Figure 1.

Reverse Corruption Perception Index for Selected Emerging Asian countries

The figure provides the corruption perception trend for 13 Emerging Asian Economies

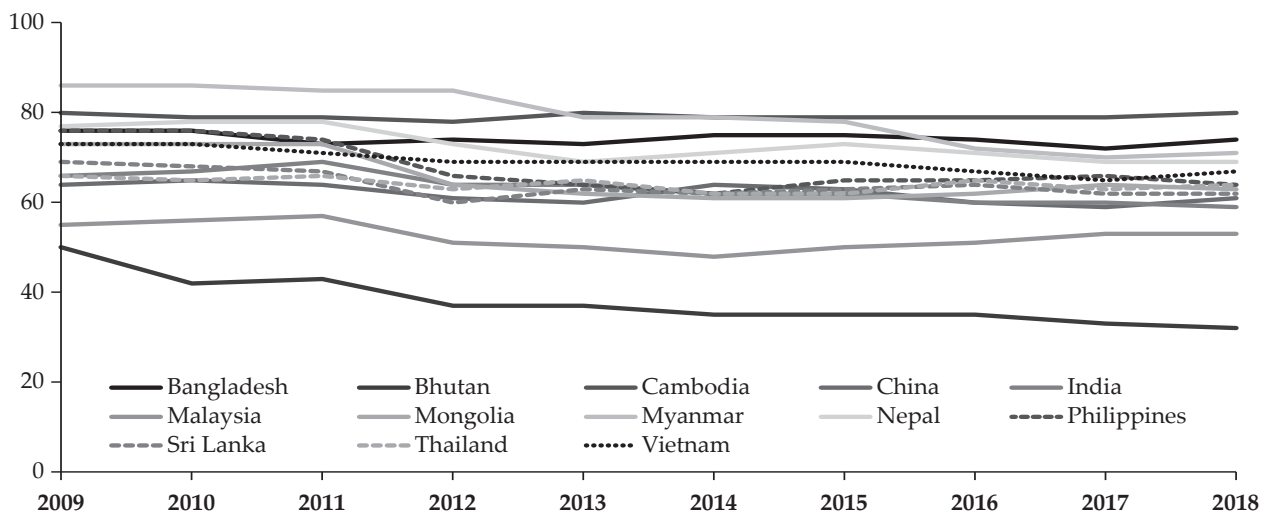

1 https://www.transparency.org/en/ 
The majority of the emerging Asian countries have scored above 50 (see Figure 1 ), and this score appears to have marginally changed through the years, save for Bhutan, which has clearly trickled down from 50 to 32 in the Reverse Corruption Perception Index score (see Figure 1). According to the Transparancy International Report (2018), globally, countries have failed to curb corruption, which, in turn, is causing a crisis in democracy ${ }^{2}$.

The Global Innovation Index (GII), on the other hand, stresses the importance of innovation-led growth. The GII Report (2018) finds that the continuous investments in breakthrough energy innovations are doing rounds in both developed and developing countries like China and India, and that regional cooperation is equally important in the race to being innovative. South East Asian countries show progress in the scores attained with the help of ASEAN (see Figure 2).

Figure 2.

\section{Global Innovation Index for Selected Emerging Asian Countries}

The figure provides the innovation trend for13 Emerging Asian Economies

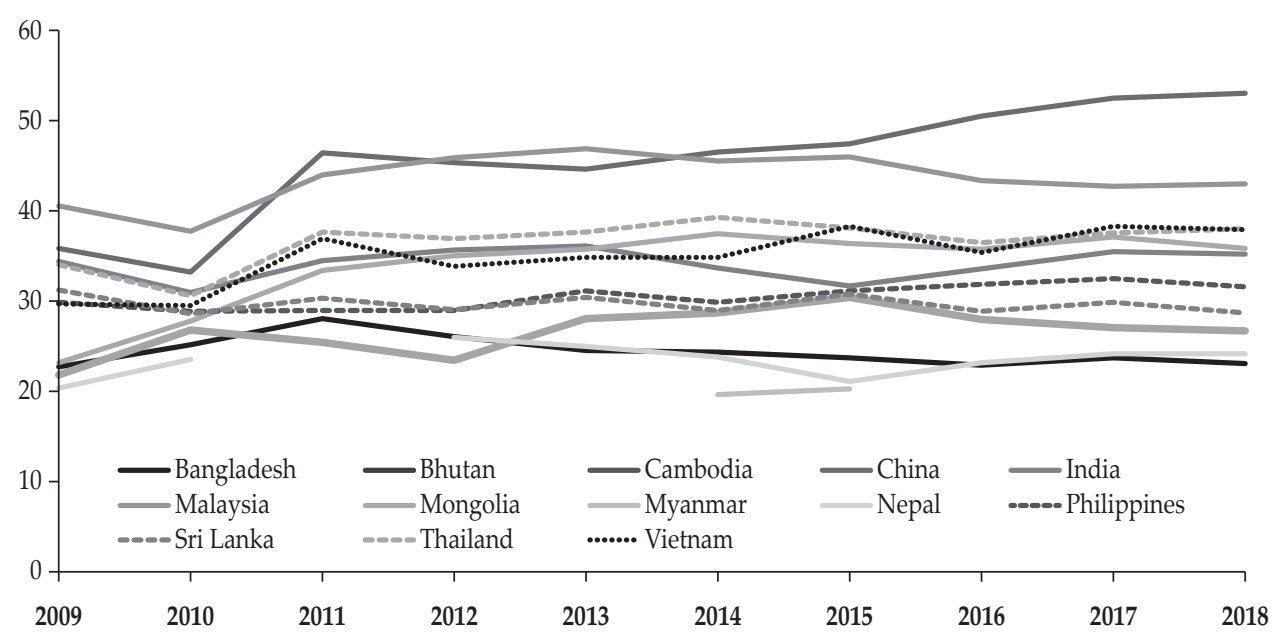

In our paper, we find that innovation does not have any significant impact on economic growth because of corruption. Even, in some of our generalised method of moments (GMM) results, we find that innovation has significantly dragged down economic growth over the years. Furthermore, corruption exerts a significantly negative impact on economic growth. Despite these findings, we noticed that financial development impacts economic growth positively. Surprisingly, we also noticed that the interaction of innovation and economic freedom has no significant impact on economic growth.

Although several studies have examined the individual impacts of corruption and innovation on growth (Campos et al., 2010; Murphy et al.,1993; Pece, Simona,

2 https://www.transparency.org/en/news/cpi-2018-global-analysis 
and Salisteanu, 2015), no study has examined their joint impact on growth. Our study bridges this research gap by examining the joint impact of corruption and innovation on economic growth, in the presence of conditioning variables like financial development and inflation. Our estimations use a dataset for 13 emerging Asian countries over the period of 2009 to 2018. This period ensures that we focus on the emerging Asian countries that fared well during the global financial crisis of 2007 to 2009 (see also Iyke and Ho, 2020). Our paper contributes to the existing literature in several ways. First, prior studies have not given due importance to factors like inflation, economic freedom, and financial development in the growth experience of the Asian economies post-global financial crisis (Grossman and Helpman, 1990; Paul, 2010; Huang, 2015). This is surprising because inflation plays a vital role in the relation among corruption, innovation, and growth. For instance, rising prices, cost overruns, and delayed projects could stimulate bribery across several sectors (Özşahin and Üçler, 2017; Blackburn and Powell, 2011). As the costs of projects rise due to the inflation, firms' funds are negatively impacted leading to reduction in the resources devoted for $R \& D$ and, consequently, a slowdown in the country's economic growth in long run (Blackburn and Powell, 2011). The other factors, economic freedom and financial development, also play key roles in shaping the relation between innovation and corruption and should be considered in growth regressions. Second, this paper produces a better insight by correlating aspects of public infrastructure to economic growth, which has not been done in the literature. Better infrastructure availability indicates an efficient economic structure with skilled innovation and lesser corrupt practices. Economies with efficient physical infrastructure have smooth innovation processes. We believe that innovation and growth are potentially better interlinked in the presence of good physical infrastructure. Third, we empirically offer a comprehensive picture of the threshold impacts of innovation on growth at various trimming scales in the presence of corruption, economic freedom, and other physical infrastructures.

These findings re-emphasize the need for combating corruption and rent seeking activities in the region. The current COVID-19 pandemic is likely to worsen the situation. Amidst the current unprecedented disruption of economies by the COVID-19 pandemic (see Devpura and Narayan, 2020; Ertugrul et al., 2020; Haroon and Rizvi, 2020; Iyke, 2020a, b; Mishra et al., 2020; Narayan, 2020a, b, c; Phan and Narayan, 2020; Prabheesh et al., 2020; Salisu and Sikiru, 2020; Sha and Sharma, 2020), policymakers in the region should pursue administrative reforms geared towards promoting transparency, efficiency, and economic freedom. Our findings suggest that such policy reforms would help harness the growth opportunities of innovative activities.

The paper is divided into five sections. The present section introduces the subject matter. Section II presents the literature review. Section III discusses the data and the methodology. Section IV presents the empirical results. Section V presents the conclusion and the policy implications of the paper.

\section{LITERATURE REVIEW}

This section reviews the literature on corruption, innovation, and economic growth. The common perception among laymen is that corruption is a hindrance 
to economic growth and development. This view is supported by some empirical studies, which find that corruption constrains economic growth and development (Campos et al., 2010; Murphy et al.,1993; Klitgard 1988; Mauro, 1995). However, other empirical studies support the idea of grease-the-wheel-effect of corruption on growth and development (Acemoglu and Verdier, 2000; Hunington, 1968; Leff, 1964; Paul 2010; Lien, 1986). In other words, these studies find that corruption enhances growth and development.

Huang (2015) finds, using data on selected Asia-Pacific countries for the period of 1997 to 2013, that there exists a significant positive causality from corruption to growth in South Korea and that anti-corruption laws may not be effective in these countries. Paul (2010) also finds a positive relationship between corruption and economic growth in Bangladesh. Corruption acts like a wage for bureaucrats, who use it as an incentive for providing public services (Acemoglu and Verdier, 2000). Corruption may also serve as a tool for entrepreneurs to sidestep regulations, which are otherwise inefficient (Acemoglu and Verdier, 2000). Thus, corruption is viewed as a lubricant and greases the wheels of the economy.

Mendez and Sepulveda (2005) examine the relationship between corruption and economic growth for a large sample of countries over the period of 1960 to 2000. Controlling for annual population growth, real income per capita, annual Gross Domestic Product (GDP) growth, secondary school enrolment rates, the investment share of GDP, and the share of government expenditures in GDP, they conclude that corruption is favourable at low levels of incidence and disadvantageous at high levels. Similarly, Gyimah-Brempong (2002) based on his empirical analysis of Africa deduces that corruption leads to lessened investments in physical capital and increased income inequality which in turn results in dampening economic growth.

Theories highlighting the impact of innovation on economic growth can be traced back to that of Schumpeter (1912), who distinguishes economic growth from development by defining economic development as a result of discontinuous internal and external changes in the economy-one of which is the role of entrepreneurs to innovate. In the Solow (1956) growth model, economic growth is sustained by growth in labour and capital, while innovation and R\&D are exogenous variables.

Moreover, Pece, Simona, and Salisteanu (2015) empirically show that innovation in Central and Eastern European countries (i.e., Poland, Czech Republic, and Hungary) ensure competitiveness and progress by ensuring private and public sector development and by improving living conditions. Grossman and Helpman (1990) show, in a theoretical model, that innovation enhances growth through comparative advantage of international trade and knowledge spillovers over international boundaries. Similarly, in their empirical studies, Maradana et al. (2017), Andergassen et al. (2009), Bae and Yoo (2015), Mansfield (1972), and Nadiri (1993) find that innovation enhances growth.

To summarize, both theoretical and empirical studies show that corruption could enhance or hurt growth and that innovation enhances growth. However, no study examines how both corruption and innovation interactively affect growth. Hence, we test the following hypotheses: 
Hypothesis (i): Corruption hurts growth in developing economies despite higher innovation rates.

Hypothesis (ii): Corruption hurts growth in developing economies in the presence of low financial development and significant improvement in physical infrastructure.

\section{DATA AND METHODOLOGY}

In order to explore the impacts of corruption and innovation on economic growth, conditional on variables like financial development, inflation, and economic freedom, we use the Corruption Perception Index (CPI), Global Innovation Index $(G I I)$, annual real GDP per capita $(E G)$, International Monetary Fund's Financial Development Index $(F D)$, Consumer Price Index, and Heritage Foundation's Economic Freedom Index $(E F)$ to measure, respectively, corruption, innovation, economic growth, financial development, inflation, and economic freedom.

The GII index is used to measure innovation owing to its comprehensiveness and inclusiveness of input as well as output pillars of the economy, which, in turn, include institutions, human capital and research, infrastructure, market, and business sophistication under the input pillars and knowledge, technology, and creative outputs under the output pillars ${ }^{3}$. The GII scores range from 0 to 100, where 0 represents the least innovative country and 100, the highly innovative country. Similarly, CPI is used to measure the level of corruption in the economy on account of its credibility because it aggregates data from 13 data sources from 12 different institutions that provide perceptions and results by business people and country level experts for the level of corruption in the public sector ${ }^{4}$. The scores, in this case, are assigned from 0 to 100, where 0 represents a high level and 100 represents a lower level of corruption.

In the light of the preceding discussion regarding the difference in reading the scores, we standardized the data for simplicity of calculations, and hence, used a Reverse Corruption Perception Index (RCPI) as our measure of corruption. The $R C P I$ ranges from 0 to 100 and the readings can be interpreted in an ascending order. Moreover, the CPI from 2009 to 2011 and the GII from 2009 to 2010 are measured based on scores ranging from 0 to 10 . Hence, for uniformity, we multiplied these values by 10 . All variables are converted into natural logarithm to avoid spurious regression issues. We have taken post 2008 data to study the impacts of innovation and corruption on economic growth in developing economies post 2008. We took the Consumer Price Index data $(2010=100)$ from the World Bank's World Development Indicators.

Our sample consists of 13 emerging Asian countries, as classified by the International Monetary Fund, for the period of 2009 to 2018. The countries are Bangladesh, Bhutan, Cambodia, China, India, Malaysia, Mongolia, Myanmar, Nepal, the Philippines, Sri Lanka, Thailand, and Vietnam. Table 1 gives the description of variables and their respective data sources.

\footnotetext{
https://www.wipo.int/global_innovation_index/en/2020/

${ }^{4}$ https://www.transparency.org/en/cpi
} 
Table 1.

Description of the variables and Data Sources

This table provides the description of variables.

\begin{tabular}{|c|c|c|c|}
\hline Variables & Symbols & Measurement & Data Source \\
\hline \multicolumn{4}{|c|}{ Dependent Variable } \\
\hline Economic Growth & $E G$ & $\begin{array}{c}\text { GDP per capita } \\
\text { (constant } 2010 \text { US\$) }\end{array}$ & WDI \\
\hline \multicolumn{4}{|c|}{ Independent Variable } \\
\hline Corruption & RCPI & Reverse Corruption Perception Index & $\begin{array}{l}\text { Transparency } \\
\text { International }\end{array}$ \\
\hline Innovation & GII & Global Innovation Index & GII \\
\hline $\begin{array}{l}\text { Financial } \\
\text { Development }\end{array}$ & $F D$ & Financial Development Index & IMF \\
\hline Inflation & INF & $\begin{array}{l}\text { Consumer Price Index } \\
\text { (Constant prices, 2010=100) }\end{array}$ & WDI \\
\hline Economic Freedom & EF & Economic Freedom Index & $\begin{array}{l}\text { Heritage } \\
\text { Foundation }\end{array}$ \\
\hline
\end{tabular}

The study utilizes several econometric techniques (i.e. simple, quantile, and threshold regression techniques). Our empirical model regresses economic growth on innovation, corruption, and several control variables documented in the literature (see Narayan and Smyth, 2005; Iyke, 2017; Takumah and Iyke, 2017; Ho and Iyke, 2018, 2020). Thus, our empirical model can be described as follows,

$$
E G_{i t}=f(G I I, R C P I, F D, I N F, E F)_{i t}
$$

The functional form can further be stated in terms of main empirical model as under,

$$
E G_{i t}=\alpha+\beta_{1} G I I_{i t}+\beta_{2} R C P I_{i t}+\beta_{3} F D_{i t}+\beta_{4} I N F_{i t}+\beta_{5} E F_{i t}+\varepsilon_{i}+\varepsilon_{t}+\varepsilon_{i t}
$$

where EG represents economic growth. $\beta_{1}, \beta_{2}, \beta_{3}, \beta_{4}$ and $\beta_{5}$ are the coefficients of innovation, corruption, financial development, inflation, and economic freedom respectively. $\varepsilon_{i}$ and $\varepsilon_{t}$ are the country and time fixed effects, respectively. Equation (2) takes into account both country and time specific effects to account for the year and country specific heterogeneities. $\varepsilon_{i t}$ is the error term. $G I_{i t^{\prime}} R C P I_{i t^{\prime}} F D_{i t^{\prime}} I N F_{i t}$ and $E F_{i t}$ denote, respectively, innovation, corruption, financial development, inflation, and economic freedom for country $i$ at time $t$. GI $_{i t}$ and $R C P I_{i t}$ are the explanatory variables of interest. The control variables are $F D_{i t^{\prime}} I N F_{i t}$ and $E F_{i t^{\prime}}$ respectively. Prior studies such as Iyke $(2017,2018)$ and Ho and Iyke $(2018,2020)$, among others also controlled for inflation and financial development as well.

In order to make our analysis more robust, we interact innovation with economic freedom in our model. This shows the joint impact of innovation and economic freedom on economic growth. Thus, Equation (2) can be rewritten as follows, 


$$
E G_{i t}=\alpha+\beta_{1}\left(G I I_{i t} * E F_{i t}\right)+\beta_{2} R C P I_{i t}+\beta_{3} F D_{i t}+\beta_{4} I N F_{i t}+\varepsilon_{i}+\varepsilon_{t}+\varepsilon_{i t}
$$

In Equation (3), the new $\beta_{1}$ denotes the coefficient of the joint interaction effects of innovation and economic freedom on economic growth.

\section{EMPIRICAL RESULTS}

Table 2.

\section{Descriptive Statistics and Correlation Matrix}

The table provides the descriptive statistics and correlation matrix of the variables. Standard errors are reported in the parentheses. $\left({ }^{*}\right),(* *)$ and $(* * *)$ denote the estimates that are significantly different from zero at $1 \%, 5 \%$ and $10 \%$ levels of significance, respectively.

\begin{tabular}{|c|c|c|c|c|c|c|}
\hline & GDP & Corruption & Innovation & Fin Dev & Inflation & $\begin{array}{c}\text { Economic } \\
\text { Freedom }\end{array}$ \\
\hline Mean & 6.929 & 4.164 & 3.002 & -0.988 & 4.296 & 4.026 \\
\hline S.D & 2.441 & 0.198 & 1.183 & 0.709 & 1.445 & 0.121 \\
\hline Maximum & 9.351 & 4.454 & 3.972 & 0.000 & 5.148 & 4.310 \\
\hline Minimum & 0.000 & 3.465 & 0.000 & -2.312 & 0.000 & 3.602 \\
\hline \multirow[t]{2}{*}{ No of obs } & 130 & 130 & 130 & 130 & 130 & 130 \\
\hline & GDP & Corruption & Innovation & Fin Dev & Inflation & $\begin{array}{c}\text { Economic } \\
\text { Freedom }\end{array}$ \\
\hline GDP & 1.000 & & & & & \\
\hline Corruption & $\begin{array}{l}-0.909 \\
(0.303)\end{array}$ & 1.000 & & & & \\
\hline Innovation & $\begin{array}{l}0.091^{* *} \\
(0.097)\end{array}$ & $\begin{array}{c}0.128^{* * *} \\
(0.123)\end{array}$ & 1.000 & & & \\
\hline $\begin{array}{l}\text { Financial } \\
\text { Development }\end{array}$ & $\begin{array}{l}-0.257^{*} \\
(0.031)\end{array}$ & $\begin{array}{l}-0.284^{*} \\
(0.001)\end{array}$ & $\begin{array}{l}0.299^{*} \\
(0.000)\end{array}$ & 1.000 & & \\
\hline Inflation & $\begin{array}{l}0.940^{*} \\
(0.000)\end{array}$ & $\begin{array}{c}0.047^{* * *} \\
(0.133)\end{array}$ & $\begin{array}{c}0.020^{* * *} \\
(0.118)\end{array}$ & $\begin{array}{l}-0.448^{*} \\
(0.000)\end{array}$ & 1.000 & \\
\hline $\begin{array}{l}\text { Economic } \\
\text { Freedom }\end{array}$ & $\begin{array}{c}0.560 \\
(0.491)\end{array}$ & $\begin{array}{l}-0.444^{*} \\
(0.000)\end{array}$ & $\begin{array}{l}0.416^{*} \\
(0.000)\end{array}$ & $\begin{array}{l}0.497^{*} \\
(0.000)\end{array}$ & $\begin{array}{c}-0.134^{* * *} \\
(0.126) \\
\end{array}$ & 1.000 \\
\hline
\end{tabular}

Table 2 shows the descriptive statistics of the variables used in our estimations. The average corruption score is 4.164 . The average financial development is negative due to the unequal pattern of financial development and countries' increasing exposure to the financial crisis. Economies like Bhutan, Bangladesh, Cambodia, Sri Lanka, Nepal, Mongolia, and the Philippines have not fared well in terms of financial structure liberalization, capital inflows, and other financial parameters. But, surprisingly, economic freedom, in terms of policy changes, has increased by 4.310 during this time period.

As far as the correlation matrix is concerned, Table 2 displays no significant correlation between GDP and corruption. However, we observe a negative correlation between rent seeking activity and GDP, implying that corruption hurts growth. The relation seems to be insignificant due to the varying degree 
of correlation across the emerging Asian countries and due to the differences in the corruption levels and the extent of corrupt practices. Still, corrupt practices at each stage notably impact innovation, growth, and financial development. We further find a positive correlation between innovation and growth-although the correlation is not significant enough to indicate that innovation certainly contributes more to growth.

\section{A. Ordinary Least Squares Estimation}

Table 3.

\section{Basic Regression Results}

The table provides the baseline regression results analysis. $\left({ }^{*}\right),\left({ }^{* *}\right)$ and $\left({ }^{* * *}\right)$ denote estimates that are significantly different from zero at the $1 \%, 5 \%$ and $10 \%$ levels of significance, respectively.

\begin{tabular}{lcccc}
\hline $\begin{array}{l}\text { Economic } \\
\text { Growth }\end{array}$ & I & II & III & IV \\
\hline Innovation & 0.033 & 0.010 & -0.022 & -0.010 \\
& $(0.032)$ & $(0.009)$ & $(0.021)$ & $(0.014)$ \\
Corruption & $-1.121^{*}$ & -0.071 & $1.267^{*}$ & $1.129^{*}$ \\
Financial & $(0.231)$ & $(0.069)$ & $(0.539)$ & $(0.240)$ \\
Development & $0.473^{*}$ & $0.570^{*}$ & $0.122^{* *}$ & $0.868^{*}$ \\
Inflation & $(0.105)$ & $(0.087)$ & $(0.066)$ & $(0.090)$ \\
& $1.708^{*}$ & $-0.677^{*}$ & $1.618^{*}$ & $-1.935^{*}$ \\
Economic Freedom & $(0.045)$ & $(0.313)$ & $(0.022)$ & $(0.418)$ \\
Time Effect & $1.150^{*}$ & -0.246 & -0.234 & $0.673^{* * *}$ \\
Country Effect & $(0.234)$ & $(0.242)$ & $(0.212)$ & $(0.429)$ \\
$R^{2}$ & No & Yes & No & Yes \\
Adjusted R $R^{2}$ & No & Yes & Yes & No \\
F-test & 0.931 & 0.993 & 0.985 & 0.975 \\
\hline
\end{tabular}

Table 3 shows the ordinary least squares (OLS) estimates of our empirical models. The estimated coefficients of innovation across models are insignificant, which shows that innovation has no direct impact on economic growth. Even if these countries experience an increase innovation, they may not experience growth because of high corruption levels, lack of efficient institutions, and prevalence of untrustworthiness. Corruption surprisingly enhances economic growth when exclusively considering time and country fixed effects separately (see columns III and IV). Several empirical studies suggest that corruption acts as an efficient grease for innovation activities (Lui, 1985; Wei, 2000; Cooray et al., 2017, Dreher and Gassebner, 2007). In support of the grease-the-wheel-hypothesis, we find that corruption exerts a positive impact on economic growth for some countries as well as over the years. 
Table 4.

\section{Regression Results (with Interaction)}

The table provides the baseline regression results analysis with interaction effect of innovation and economic freedom. $\left.\left.{ }^{*}\right),{ }^{(* *}\right)$ and $\left(^{* * *}\right)$ denote estimates that are significantly different from zero at the $1 \%, 5 \%$ and $10 \%$ levels of significance, respectively.

\begin{tabular}{lcccc}
\hline Economic Growth & I & II & III & IV \\
\hline Innovation ${ }^{*}$ Economic & 0.190 & -0.060 & 0.034 & 0.051 \\
Freedom & $(0.170)$ & $(0.059)$ & $(0.033)$ & $(0.049)$ \\
Corruption & $-1.204^{*}$ & $1.342^{*}$ & $-1.308^{*}$ & -0.013 \\
& $(0.375)$ & $(0.511)$ & $(0.211)$ & $(0.013)$ \\
Financial Development & $0.560^{*}$ & $0.116^{* *}$ & $0.904^{*}$ & $0.568^{*}$ \\
& $(0.105)$ & $(0.064)$ & $(0.088)$ & $(0.086)$ \\
Inflation & $1.717^{*}$ & $1.619^{*}$ & $-2.126^{*}$ & $-0.563^{*}$ \\
& $(0.046)$ & $(0.022)$ & $(0.403)$ & $(0.314)$ \\
Constant & $4.930^{*}$ & $-6.485^{*}$ & $2.834^{*}$ & $1.671^{*}$ \\
Time Effect & $(1.319)$ & $(2.221)$ & $(0.105)$ & $(0.073)$ \\
Country Effect & No & No & Yes & Yes \\
Region & No & Yes & No & Yes \\
$R^{2}$ & Full Panel & Full Panel & Full Panel & Full Panel \\
Adjusted $R^{2}$ & 0.926 & 0.986 & 0.974 & 0.993 \\
\hline
\end{tabular}

Prior studies show that high economic freedom is associated with high corporate innovation in the domiciled countries. That is, firms domiciled in a country with an efficient regulatory system, limited government interference, and open markets are more innovative (see Zhu and Zhu, 2017). Therefore, it is possible that the impact of innovation on growth is better observed through economic freedom. In order to get a more robust impact of innovation on growth, we interact innovation with economic freedom; this also measures the joint impact of innovation and economic freedom on growth. The estimates, which are reported in Table 4, show that innovation enhances growth through economic freedom.

\section{B. Quantile Regression}

We utilize the quantile regression method developed by Koenker and Bassett (1978) to estimate the impacts of corruption and innovation on economic growth at various quantiles and compare the estimates to those of the simple regression method. The quantile regression method overcomes the problem of heterogeneity of variances by fitting linear regressions on different quantiles of the response variable (Koenker and Bassett, 1978).

Economic growth might differ across emerging economies but we cannot rule them out as the outliers. Hence, it is meaningful to calculate the coefficients at various quantiles by utilizing the conditional distribution of the explained variable (Coad and Rao, 2006; Uddin et al., 2017). By relaxing these assumptions, country specific heterogeneities are taken into the consideration to a greater extent. 
Table 5.

\section{Quantile Regression Results}

The table provides the quantile regression results. Standard errors are given in parentheses under the values of coefficients. $\left({ }^{*}\right),\left({ }^{* *}\right)$ and $\left({ }^{* *}\right)$ denote estimates that are significantly different from zero at the $1 \%, 5 \%$ and $10 \%$ levels of significance, respectively.

\begin{tabular}{lcccc}
\hline Economic Growth & I & II & III & IV \\
\hline \multirow{2}{*}{ Innovation } & 0.083 & $-0.105^{* * *}$ & -0.081 & $-0.125^{* *}$ \\
& $(0.082)$ & $(0.064)$ & $(0.057)$ & $(0.081)$ \\
Corruption & $-0.781^{*}$ & $-0.536^{*}$ & $-0.404^{* * *}$ & $-0.691^{*}$ \\
& $(0.316)$ & $(0.257)$ & $(0.247)$ & $(0.325)$ \\
Financial Development & $0.199^{* * *}$ & $0.869^{*}$ & $1.037^{*}$ & $1.012^{*}$ \\
& $(0.130)$ & $(0.176)$ & $(0.144)$ & $(0.152)$ \\
Inflation & $1.570^{*}$ & $1.827^{*}$ & $1.950^{*}$ & $1.963^{*}$ \\
& $(0.048)$ & $(0.061)$ & $(0.044)$ & $(0.041)$ \\
Economic Freedom & $0.709^{*}$ & $0.646^{*}$ & $0.498^{* *}$ & $0.846^{*}$ \\
Quantiles & $(0.296)$ & $(0.279)$ & $(0.260)$ & $(0.348)$ \\
Pseudo $R^{2}$ & $25^{\text {th }}$ & $50^{\text {th }}$ & $75^{\text {th }}$ & $90^{\text {th }}$ \\
Adjusted $R^{2}$ & 0.730 & 0.638 & 0.625 & 0.635 \\
\hline
\end{tabular}

Table 5 shows the quantile regression estimates. Innovation has the surprisingly negative effect on economic growth, especially in the earlier stages of 2009-10. Corruption has negative impact on economic growth at various quantiles (see columns I to IV). Like the OLS estimates, the quantile estimates show a positive and significant correlation between financial development and economic growth at $1 \%$ level of statistical significance. Other variables, like inflation and economic freedom, exhibit positive and significant relation with economic growth.

Table 6.

\section{Quantile Regression Results (with Interaction)}

The table provides the quantile regression results with interaction effects. Standard errors are given in parentheses under the values of coefficients. $\left.\left(^{*}\right),{ }^{* *}\right)$ and $\left(^{* * *}\right)$ denote estimates that are significantly different from zero at the $1 \%$, $5 \%$ and $10 \%$ levels of significance, respectively.

\begin{tabular}{lcccc}
\hline Economic Growth & I & II & III & IV \\
\hline Innovation ${ }^{*}$ Economic & 0.285 & -0.243 & -0.204 & -0.107 \\
Freedom & $(0.216)$ & $(0.240)$ & $(0.149)$ & $(0.102)$ \\
Corruption & $-0.826^{*}$ & -0.340 & $-0.558^{* *}$ & $-0.910^{*}$ \\
& $(0.413)$ & $(0.327)$ & $(0.294)$ & $(0.340)$ \\
Financial Development & $0.208^{* * *}$ & $0.932^{*}$ & $1.013^{*}$ & $1.015^{*}$ \\
& $(0.134)$ & $(0.161)$ & $(0.092)$ & $(0.110)$ \\
Inflation & $1.553^{*}$ & $1.850^{*}$ & $1.940^{*}$ & $1.964^{*}$ \\
& $(0.059)$ & $(0.071)$ & $(0.041)$ & $(0.049)$ \\
Constant & $3.085^{* *}$ & 1.698 & $2.591^{*}$ & $4.108^{*}$ \\
Quantiles & $(1.678)$ & $(1.661)$ & $(1.154)$ & $(1.382)$ \\
Pseudo $R^{2}$ & $25^{\mathrm{TH}}$ & $50^{\mathrm{TH}}$ & $75^{\mathrm{TH}}$ & $90^{\mathrm{TH}}$ \\
\hline
\end{tabular}


Table 6 contains the quantile regression estimates for the model with innovation and economic freedom interaction term. We find that the interaction between innovation and economic freedom has no effect on economic growth at various quantiles. Asian developing economies being primarily mixed economies, we find no significant relation with economic growth, except in India and China. We find that corruption exerted a negative impact on growth due to major rent seeking activities across sectors. Our empirical estimates show that inflation and financial development have a positive and significant effect on economic growth in these economies at the conventional level of significance.

\section{Robustness Check}

To overcome the problem of endogeneity, we applied GMM techniques. In our GMM estimations, we applied both the difference and system GMM estimators. The explanatory variables in the basic regression are potentially correlated with the error term, which can bias the coefficients.

\section{Table 7. GMM Results}

This table provides Generalized Methods of Moments results. Standard errors are given in parentheses under the values of coefficients. $\left({ }^{*}\right),\left({ }^{* *}\right)$ and $\left(^{* * *}\right)$ denote estimates that are significantly different from zero at the $1 \%, 5 \%$ and $10 \%$ levels of significance, respectively.

\begin{tabular}{lcc}
\hline Economic Growth & I & II \\
\hline Economic Growth (-1) & $-0.857^{*}$ & $-0.480^{*}$ \\
& $(0.150)$ & $(0.186)$ \\
Innovation & $-0.010^{* *}$ & $-0.032^{* *}$ \\
& $(0.005)$ & $(0.017)$ \\
Corruption & $-0.365^{*}$ & $0.190^{*}$ \\
& $(0.131)$ & $(0.078)$ \\
Financial Development & $0.070^{*}$ & 0.034 \\
& $(0.034)$ & $(0.029)$ \\
Inflation & $1.560^{*}$ & $1.597^{*}$ \\
& $(0.042)$ & $(0.039)$ \\
Economic Freedom & -0.317 & -0.189 \\
& $(0.312)$ & $(0.182)$ \\
Constant & $9.376^{*}$ & 3.832 \\
& $(2.466)$ & $(2.685)$ \\
Model & Arellano Bond Difference GMM & System GMM \\
\hline No of instruments & 14 & 22 \\
Sargan $p$-value & 0.324 & 0.947 \\
AR $(1) p$-value & 0.019 & 0.133 \\
AR (2) $p$-value & 0.149 & 0.168 \\
\hline
\end{tabular}

Table 7, which shows the results, indicate that innovation has a negative impact on economic growth using both the difference and system GMM estimates. The results suggest that the presence of corruption led to the inverse relation between innovation and economic growth, which is consistent with the empirical studies demonstrating that innovation slows down economic growth in the presence 
of corruption (Goedhuys et al., 2016; Anokhin and Schulze, 2009; Asiedu and Freeman, 2009; Paunov, 2016). Like our previous estimates, our GMM estimates show negative and significant relation between corruption and economic growth. Economic freedom has no significant relation with economic growth from GMM estimates. Our post-estimation results are consistent and robust, as evidenced by the Sargan and autocorrelation (AR) tests.

Table 8.

GMM Results (with interaction)

This table provides Generalized Methods of Moments results with interaction effect. Standard errors are given in parentheses under the values of coefficients. $\left({ }^{*}\right),\left({ }^{* *}\right)$ and $\left({ }^{* * *}\right)$ denote the estimates that are significantly different from zero at the $1 \%, 5 \%$ and $10 \%$ levels of significance, respectively.

\begin{tabular}{lcc}
\hline Economic Growth & I & II \\
\hline Economic Growth (-1) & $-0.926^{*}$ & $-0.604^{*}$ \\
& $(0.162)$ & $(0.176)$ \\
Innovation ${ }^{*}$ Economic Freedom & 0.011 & $-0.132^{* *}$ \\
Corruption & $(0.012)$ & $(0.070)$ \\
& $-0.321^{*}$ & $0.349^{*}$ \\
Financial Development & $(0.124)$ & $(0.083)$ \\
& $0.070^{*}$ & $0.043^{*}$ \\
Inflation & $(0.031)$ & $(0.015)$ \\
& $1.561^{*}$ & $1.583^{*}$ \\
Constant & $(0.034)$ & $(0.038)$ \\
& $8.493^{*}$ & $3.379^{*}$ \\
Model & $(1.472)$ & $(1.428)$ \\
\hline No of instruments & Arellano-Bond Dynamic GMM & 21 \\
Sargan $p$-value & 13 & 0.911 \\
AR $(1) p$-value & 0.366 & 0.103 \\
AR $(2) p$-value & 0.130 & 0.155 \\
\hline
\end{tabular}

In Table 8, we introduced the interaction between innovation and economic freedom in the model and estimate it using the GMM estimators. We noticed that the interaction term has a negative impact on growth in the presence of more instruments. We found that lagged economic growth impacts growth negatively and significantly at the conventional level of significance (see columns I and II). Our empirical results furthermore show that inflation and financial development have a positive and significant impact on growth at the conventional level of significance, indicating that an increase in inflation and financial development leads to an increase in economic growth. 
D. Sensitivity test

Table 9.

Threshold Regression Result

This table presents the threshold regression result with innovation being the threshold variable. Standard errors are given in parentheses under the values of coefficients. $\left({ }^{*}\right),\left({ }^{* *}\right)$ and $\left({ }^{* * *}\right)$ denote the estimates that are significantly different from zero at the $1 \%, 5 \%$ and $10 \%$ levels of significance, respectively.

\begin{tabular}{lcccc}
\hline Economic Growth & I & II & III & IV \\
\hline Innovation & $-0.103^{*}$ & $-0.102^{*}$ & $-0.088^{* *}$ & $-0.118^{*}$ \\
& $(0.042)$ & $(0.042)$ & $(0.047)$ & $(0.045)$ \\
Corruption & $1.706^{*}$ & $1.651^{*}$ & $1.522^{*}$ & $1.508^{*}$ \\
& $(0.500)$ & $(0.499)$ & $(0.512)$ & $(0.492)$ \\
Financial Development & 0.082 & $0.095^{* * *}$ & 0.073 & 0.059 \\
& $(0.062)$ & $(0.062)$ & $(0.065)$ & $(0.053)$ \\
Inflation & $1.538^{*}$ & $1.542^{*}$ & $1.542^{*}$ & $1.523^{*}$ \\
& $(0.026)$ & $(0.026)$ & $(0.032)$ & $(0.030)$ \\
Economic Freedom & 0.103 & 0.014 & -0.093 & -0.009 \\
& $(0.104)$ & $(0.013)$ & $(0.092)$ & $(0.008)$ \\
Constant & $-7.123^{*}$ & $-6.537^{* *}$ & $-5.603^{* * *}$ & $-5.503^{* *}$ \\
Threshold variable & $(3.145)$ & $(3.428)$ & $(3.526)$ & $(3.404)$ \\
Trimming & Innovation & Innovation & Innovation & Innovation \\
Regime 1 & 0.010 .010 .01 & 0.050 .050 .05 & 0.100 .100 .10 & 0.200 .200 .20 \\
& $0.040^{*}$ & $0.042^{*}$ & $0.031^{* *}$ & 0.015 \\
Regime 2 & $(0.013)$ & $(0.013)$ & $(0.018)$ & $(0.014)$ \\
& $0.055^{*}$ & & & $0.050^{*}$ \\
Regime 3 & $(0.016)$ & & & $(0.016)$ \\
$R^{2}$ & $0.072^{*}$ & $0.063^{*}$ & $0.066^{*}$ & $0.074^{*}$ \\
F-test & $(0.015)$ & $(0.014)$ & $(0.018)$ & $(0.016)$ \\
\hline
\end{tabular}

We performed a sensitivity test by employing a threshold regression test. Table 9 shows these results. We find that innovation has a negative and significant impact on growth at $1 \%$ level of significance. We also found that, with further trimming, innovation has a negative and significant impact on economic growth. The threshold regression results suggest that an increase in corruption is associated with an increase in economic growth due to high rent seeking activities (see columns I to IV). Unlike the other regression results, these results indicate that innovation has a positive and significant impact on growth at the conventional levels of significance. However, economic freedom has no significant impact on economic growth (see Table 9).

\section{CONCLUSION}

We show that innovation has either no significant or a negative impact on economic growth. Hence, our study documents that the least positive spillover effects of innovation and corruption in the emerging Asian region is primarily due to the differences in innovation patterns across countries, lack of effective R\&D 
facilities, and to the prevalence of corruption. We show that corruption slowed down economic growth in the region, consistent with prior empirical findings (Luo, 2005; Ankhoin and Schultz, 2009). In some of our empirical estimates, like the sensitivity estimates, we found that corruption enhances economic growth in the presence of innovation (as a threshold variable). This implies that corruption, in some cases, stimulates innovation activities. We also found that, due to the variations in economy-specific institutional frameworks, macroeconomic, and political stabilities, economic freedom exerted no significant impact on growth. Overall, the results indicate that innovation in the region is not robust enough to attract additional economic growth and that corruption is the major hindrance to long-run growth.

We found that the impact of innovation on economic growth in most emerging Asian countries is insignificant. We found the same evidence for the interaction effect of innovation and economic freedom on growth. One of the reasons attributable to such results may be the lack of adequate allocation of R\&D expenditure towards the R\&D sector. This is affirmed by UNESCO's Sustainable Development Goals Report of 2018, which suggested that the South and West Asia spent only 0.1 to 0.6 percent of their GDP on R\&D activities. In order to fuel efficient innovative and sustainable economies, the emerging Asian countries should reform their administrations to become more transparent.

\section{REFERENCES}

Acemoglu, D., \& Verdier, T. (2000). The Choice Between Market Failures and Corruption. American Economic Review, 90, 194-211.

Andergassen, R., Nardini, F., \& Ricottilli, M. (2009). Innovation and Growth Through Local and Global Interaction. Journal of Economic Dynamics and Control, 33, 1779-1795.

Andergassen, R., Nardini, F., \& Ricottilli, M. (2009). Innovation and Growth Through Local and Global Interaction. Journal of Economic Dynamics and Control, 33, 1779-1795.

Asiedu, E., \& Freeman, J. (2009). The Effect Of Corruption On Investment Growth: Evidence from Firms in Latin America, Sub-Saharan Africa, and Transition Countries. Review of Development Economics, 13, 200-214.

Bae, S. H., \& Yoo, K. (2015). Economic Modeling of Innovation in the Creative Industries and its Implications. Technological Forecasting and Social Change, 96, 101-110.

Blackburn, K., \& Powell, J. (2011). Corruption, Inflation and Growth. Economics Letters, 113, 225-227.

Brockman, P., Khurana, I. K., \& Zhong, R. I. (2018). Societal Trust and Open Innovation. Research Policy, 47, 2048-2065.

Campos, N. F., Dimova, R. D., \& Saleh, A. (2010). Whither Corruption? A Quantitative Survey of the Literature on Corruption and Growth. CEPR Discussion Paper No. DP8140.

Cooray, A., Dzhumashev, R., \& Schneider, F. (2017). How Does Corruption Affect Public Debt? An Empirical Analysis. World Development, 90, 115-127.

Devpura, N., \& Narayan, P.K., (2020) Hourly Oil Price Volatility: The Role of COVID-19, Energy Research Letters, 1, 13683. https://doi.org/10.46557/001c.13683 
Dincer, O. (2019). Does Corruption Slow Down Innovation? Evidence from a Cointegrated Panel of US States. European Journal of Political Economy, 56, 1-10.

Doh, S., \& Acs, Z. J. (2010). Innovation and Social Capital: A Cross-Country Investigation. Industry and Innovation, 17, 241-262.

Domar, E. D. (1946). Capital Expansion, Rate of Growth, and Employment. Econometrica, Journal of the Econometric Society, 137-147.

Dreher, A., \& Gassebner, M. (2007). Greasing the Wheels of Entrepreneurship. The Impact of Regulations and Corruption on Firm Entry (Working Paper, 2013). CESifo.

Ertugrul, H.M., Gungor, B.O., \& Soytas, U. (2020). Effect of COVID-19 Outbreak on Turkish Diesel Consumption Volatility Dynamics. Energy Research Letters,1(3). https://doi.org/10.46557/001c.17496

Goedhuys, M., \& Sleuwaegen, L. (2016). International Standards Certification, Institutional Voids and Exports from Developing Country Firms. International Business Review, 25, 1344-1355.

Grossman, G. M., \& Helpman, E. (1990). Trade, Innovation, and Growth (No. 21232018-4877).

Gyimah-Brempong, K. (2002). Corruption, Economic Growth, and Income Inequality in Africa. Economics of Governance, 3, 183-209.

Habibov, N., Barrett, B. J., \& Chernyak, E. (2017). Understanding Women's Empowerment and Its Determinants in Post-Communist Countries: Results of Azerbaijan National Survey. Women's Studies International Forum, 62, 125-135.

Haroon, O., \& Rizvi, S.A.R. (2020) Flatten the Curve and Stock Market Liquidity An Inquiry into Emerging Economies. Emerging Markets Finance and Trade, 56, 2151-2161. https://doi.org/10.1080/1540496X.2020.1784716.

Harrod, R. F. (1939). An Essay in Dynamic Theory. The Economic Journal, 49, 14-33.

Ho, S. Y., \& Iyke, B. N. (2018). Finance-Growth-Poverty Nexus: A Re-Assessment of the Trickle-Down Hypothesis in China. Economic Change and Restructuring, 51, 221-247.

Ho, S. Y., \& Iyke, B. N. (2020). The Determinants of Economic Growth in Ghana: New Empirical Evidence. Global Business Review, 21, 626-644.

Hsu, P. H., Tian, X., \& Xu, Y. (2014). Financial Development and Innovation: CrossCountry Evidence. Journal of Financial Economics, 112, 116-135.

Huang, Y. (2015) Arresting Corruption in China-Why China's Form of Corruption Is So Unique? The Diplomat.

Index, G. I. (2018). Energizing the World with Innovation. https://www. globalinnovationindex. org/gii-2017-report.

Iyke, B. N. (2017). Does Trade Openness Matter for Economic Growth in the CEE countries?. Review of Economic Perspectives, 17, 3-24.

Iyke, B. N. (2018). The Real Effect of Currency Misalignment on Productivity Growth: Evidence from Middle-Income Economies. Empirical Economics, 55, 1637-1659.

Iyke, B. (2020a). COVID-19: The Reaction of US Oil and Gas Producers to the Pandemic. Energy Research Letters, 1, 13912. https://doi.org/10.46557/001c.13912

Iyke, B.N. (2020b). The Disease Outbreak Channel of Exchange Rate Return Predictability: Evidence from COVID-19. Emerging Markets Finance and Trade, 56, 2277-2297. https://doi.org/10.1080/1540496X.2020.1784718

Iyke, B. N., \& Ho, S. Y. (2020). Consumption and Exchange Rate Uncertainty: Evidence from Selected Asian countries. The World Economy, 43, 2437-2462. 
Juhro, S. M., Narayan, P. K., Iyke, B. N., \& Trisnanto, B. (2020). Is There A Role For Islamic Finance and R\&D in Endogenous Growth Models in the Case of Indonesia?. Pacific-Basin Finance Journal. https://doi.org/10.1016/j. pacfin.2020.101297.

Klitgaard, Robert E. (1988). Controlling Corruption. Univ. of California Press.

Koenker, R., \& Bassett Jr, G. (1978). Regression Quantiles. Econometrica: journal of the Econometric Society, 33-50.

Lee, Y., \& Gordon, R. H. (2005). Tax structure and economic growth. Journal of Public Economics, 89, 1027-1043.

Leff, N. H. (1964). Economic Development through Bureaucratic Corruption. American Behavioral Scientist, 8, 8-14.

Lien, D. H. D. (1986). A Note on Competitive Bribery Games. Economics Letters, 22, 337-341.

Lui, F. T. (1985). An Equilibrium Queuing Model of Bribery. Journal of Political Economy, 93, 760-781.

Luo, Y. (2005). An Organizational Perspective of Corruption. Management and Organization Review, 1, 119-154.

Mansfield, E. (1972). Research and innovation in the modern corporation. Springer.

Maradana, R. P., Pradhan, R. P., Dash, S., Gaurav, K., Jayakumar, M., \& Chatterjee, D. (2017). Does Innovation Promote Economic Growth? Evidence from European countries. Journal of Innovation and Entrepreneurship, 6, 1.

Mauro, P. (1995). Corruption and Growth. The Quarterly Journal of Economics, 110, 681-712.

Méndez, F., \& Sepúlveda, F. (2006). Corruption, Growth and Political Regimes: Cross Country Evidence. European Journal of political economy, 22, 82-98.

Mishra, A.K., Rath, B.N., \& Dash, A.K. (2020). Does the Indian financial Market Nosedive because of the COVID-19 Outbreak, in Comparison to after Demonetisation and the GST? Emerging Markets Finance and Trade, 56, 21622180. https://doi.org/10/1080/1540496X.2020.1785425.

Murphy, Kevin M., Shleifer, Andrei, \& Vishny, Robert W. (1993). Why is RentSeeking So Costly to Growth? American Economic Review, 83, 409-414.

Nadiri, M. I. (1993). Innovations and technological spillovers (No. w4423). National Bureau of Economic Research.

Narayan, P. K. (2020a). Oil Price News and COVID-19-Is There Any Connection?. Energy Research Letters, 1, 13176. https://doi.org/10.46557/001c.13176.

Narayan, P. K. (2020b). Did Bubble Activity Intensify During COVID-19? Asian Economics Letters, 1(2). https://doi.org/10.46557/001c.17654.

Narayan, P. K. (2020c). Has COVID-19 Changed Exchange Rate Resistance to Shocks? Asian Economics Letters, 1. https://doi.org/10.46557/001c.17389

Narayan, P., \& Smyth, R. (2005). Trade Liberalization and Economic Growth in Fiji. An Empirical Assessment Using the ARDL approach. Journal of the Asia Pacific Economy, 10, 96-115. https://doi.org/10.1080/1354786042000309099

North, D. (1993). Institutions and Economic Performance. Rationality, Institutions and Economic Methodology, 242-261.

Özşahin, Ş., \& Üçler, G. (2017). The consequences of corruption on inflation in developing countries: Evidence from Panel Cointegration and Causality Tests. Economies, 5, 49. 
Paul, B. P. (2010). Does Corruption Foster Growth in Bangladesh?. International Journal of Development Issues, 9, 246-262.

Paunov, C., \& Rollo, V. (2016). Has the Internet fostered Inclusive Innovation in the Developing World? World Development, 78, 587-609.

Pece, A. M., Simona, O. E. O., \& Salisteanu, F. (2015). Innovation and Economic Growth: An Empirical Analysis for CEE Countries. Procedia Economics and Finance, 26, 461-467.

Phan, D.H.B., \& Narayan, P.K., (2020) Country Responses and the Reaction of the Stock Market to COVID-19-a Preliminary Exposition. Emerging Markets Finance and Trade, 56, 2138-2150. https://doi.org/10.1080/1540496X.2020.1784719

Pharr, Susan J., \& Putnam, R, D. (2000). Disaffected Democracies: What's Troubling the Trilateral Countries? Princeton University Press.

Prabheesh, K.P., Padhan, R., \& Garg, B., (2020) COVID-19 and the Oil Price-Stock Market Nexus: Evidence from Net Oil-Importing Countries, Energy Research Letters, 1, 13745. https://doi.org/10.46557/001c.13745

Romer, P. M. (1994). The Origins of Endogenous Growth. Journal of Economic perspectives, 8, 3-22.

Salisu, A. A., \& Sikiru, A. A. (2020). Pandemics and the Asia-Pacific Islamic stocks. Asian Economics Letters, 1. https://doi.org/10.46557/001c.17413.

Schumpeter, J. A. (1912). The Theory of Economic Development. Harvard University Press: Harvard.

Sha, Y., and Sharma, S.S. (2020). Research on Pandemics. Special Issue of the Journal Emerging Markets Finance and Trade, 56, 2133-2137. https://doi.org/10.1 080/1540496X.2020.1795467

Solow, R. M. (1956). A Contribution to the Theory of Economic Growth. The Quarterly Journal of Economics, 70, 65-94.

Takumah, W., \& Iyke, B. N. (2017). The Links Between Economic Growth and Tax Revenue in Ghana: an empirical investigation. International Journal of Sustainable Economy, 9, 34-55.

Tanzi, V. (1998). Corruption around the World: Causes, Consequences, Scope, and Cures. IMF Staff Papers, 45, 559-594.

Teorell, J. (2007). Corruption as an Institution: Rethinking The Nature and Origins of the Grabbing Hand. QoG Working Paper Series, 5, 1-24.

Uddin, M. A., Ali, M. H., \& Masih, M. (2017). Political Stability And Growth: An Application Of Dynamic GMM and Quantile Regression. Economic Modelling, 64, 610-625.

Uzawa, H. (1964). Optimal growth in A Two-Sector Model of Capital Accumulation. The Review of Economic Studies, 31, 1-24.

Wei, S. J. (2000). How Taxing Is Corruption on International Investors? Review of Economics and Statistics, 82, 1-11.

Wright, A. S., \& Craigwell, R. (2012). Economic Growth and Corruption in Developing Economies: Evidence from Linear and Non-Linear Panel Causality Tests. Journal of Business, Finance and Economics in Emerging Economies, 8, 23-43.

Zhu, H., \& Zhu, S. X. (2017). Corporate Innovation and Economic Freedom: CrossCountry Comparisons. The Quarterly Review of Economics and Finance, 63, 50-65. 